Review

\title{
The Association of Gut Microbiota and Complications in Gastrointestinal-Cancer Therapies
}

\author{
Kevin M. Tourelle ${ }^{1}$, Sebastien Boutin ${ }^{2}(0)$, Markus A. Weigand ${ }^{1}$ and Felix C. F. Schmitt ${ }^{1, * \mathbb{C}}$ \\ 1 Department of Anaesthesiology, Heidelberg University Hospital, 420, Im Neuenheimer Feld, \\ D-69120 Heidelberg, Germany; kevin.tourelle@med.uni-heidelberg.de (K.M.T.); \\ markus.weigand@med.uni-heidelberg.de (M.A.W.) \\ 2 Department of Infectious Disease, Medical Microbiology and Hygiene, Heidelberg University Hospital, 324, \\ Im Neuenheimer Feld, D-69120 Heidelberg, Germany; sebastien.boutin@med.uni-heidelberg.de \\ * Correspondence: felix.schmitt@med.uni-heidelberg.de
}

check for updates

Citation: Tourelle, K.M.; Boutin, S. Weigand, M.A.; Schmitt, F.C.F. The Association of Gut Microbiota and Complications in Gastrointestinal-Cancer Therapies. Biomedicines 2021, 9, 1305. https://doi.org/10.3390/

biomedicines 9101305

Academic Editor: Ryota Niikura

Received: 30 August 2021

Accepted: 21 September 2021

Published: 24 September 2021

Publisher's Note: MDPI stays neutral with regard to jurisdictional claims in published maps and institutional affiliations.

Copyright: (c) 2021 by the authors. Licensee MDPI, Basel, Switzerland. This article is an open access article distributed under the terms and conditions of the Creative Commons Attribution (CC BY) license (https:/ / creativecommons.org/licenses/by/ $4.0 /)$.

\begin{abstract}
The therapy of gastrointestinal carcinomas includes surgery, chemo- or immunotherapy, and radiation with diverse complications such as surgical-site infection and enteritis. In recent years, the microbiome's influence on different diseases and complications has been studied in more detail using methods such as next-generation sequencing. Due to the relatively simple collectivisation, the gut microbiome is the best-studied so far. While certain bacteria are sometimes associated with one particular complication, it is often just the loss of alpha diversity linked together. Among others, a strong influence of Fusobacterium nucleatum on the effectiveness of chemotherapies is demonstrated. External factors such as diet or specific medications can also predispose to dysbiosis and lead to complications. In addition, there are attempts to treat developed dysbiosis, such as faecal microbiota transplant or probiotics. In the future, the underlying microbiome should be investigated in more detail for a better understanding of the precipitating factors of a complication with specific therapeutic options.
\end{abstract}

Keywords: gastrointestinal cancer; colorectal cancer; gastric cancer; oesophageal cancer; microbiome; 16S rRNA; next-generation sequencing; complications; cancer therapy

\section{Introduction}

In recent years, there has been increasing interest in the study of the microbiome. The microbiome of a $70 \mathrm{~kg}$ human is about $3.8 \times 10^{13}$ bacterial cells, making up a total weight of about $200 \mathrm{~g}$. In comparison, humans are composed of about $3.0 \times 10^{13}$ human cells [1]. The microbiome comprises bacteria, viruses, fungi, bacteriophages, and protozoa. Those can interact in symbiosis or dysbiosis with their host. Different microbiomes can be investigated with different approaches and for various diseases. The colon, lungs, or the naso-oral area have different microbiome compositions. Many diseases show abnormalities in terms of an altered microbiome. The ability to study the microbiome in more detail using next-generation sequencing (NGS) provides new insight. NGS can analyse all DNA fragments, and thus identify and differentiate bacteria, fungi, and viruses from human DNA [2-4].

To date, no healthy baseline for a microbiome has been found. However, due to the many studies, we know that diversity and functional redundancy are key players to establish a balance in the gut microbiome [5]. Recent works also highlighted the impact of environmental factors such as diet, drugs, and anthropometric states rather than that of genetics in shaping the gut microbiome [6]. The Westernised diet and industrialization shift the gut microbiome to a pathobiont-orientated state by modifying the balance between Firmicutes and Bacteroidetes [5,7]. Those two phyla are mostly relevant due to their metabolic function and their complementarity in the production of short-chain fatty acids (SCFAs), which impact the human metabolism and immune system [8-10]. The imbalance of the gut 
microbiome, also called dysbiosis, induces a decrease in the control of the pathogens by commensals and by the immune system, which leads to a pathobiome [11]. Since every patient shows an individual microbiome, and the immune system and functional redundancy relate to strain-level resolution in function and immune recognition [5], a patient-specific baseline is required for a reliable assessment. To detect changes through interventions, the microbiome must be compared before and after an intervention. To avoid subsequent shifts after the intestinal microbiome is collected in the stool, the microbiome must be collected in specific preservation tubes and cooled as quickly as possible or preferably frozen at $-80^{\circ} \mathrm{C}$ until evaluation. The shorter the period between collection and preservation is, the more accurate results are [12,13].

The most common gastrointestinal cancers are oesophageal, gastric, and colorectal carcinomas. For all carcinomas globally, the colon carcinoma accounts for $6.1 \%$, gastric carcinoma for $5.7 \%$, rectal carcinoma for $3.9 \%$, and oesophageal carcinoma for $3.2 \%$. Of all cancers, $5.8 \%$ of patients died from colon cancer, $8.2 \%$ from gastric cancer, $3.2 \%$ from rectal cancer, and $5.3 \% \%$ from oesophageal cancer [14]. Studies showed that certain bacteria and compositions of the microbiome may be responsible for the development of colorectal cancer. For example, Escherichia coli and Bacteroides fragilis were associated with earlier tumour onset and increased morbidity in mouse models [15]. In addition, Fusobacterium nucleatum is associated with tumorigenesis in colorectal cancer [16]. Furthermore, the microbiome differs in left- and right-side colorectal cancer $[17,18]$. The challenge of distinguishing whether certain bacteria have a selective advantage due to cancer, and are therefore more detectable in cancer patients, or whether certain bacteria promote cancer development remains unclear.

In this review, we present the current status of the microbiome concerning therapeutic options for gastrointestinal carcinoma. More specifically, we show which complications are associated with the gut microbiome and, where possible, which bacterium, species, or phylum shows associated complications.

\section{Materials and Methods}

We completed a scientific search via PubMed in July 2021 to investigate microbiomeassociated complications related to gastrointestinal-cancer treatment options. Human and animal studies, and studies with cell lines were included. Meta-analyses, RCTs, controlled trials, and case reports were also considered in this review. To screen relevant papers, "gastrointestinal cancer", "gastric cancer", oesophageal cancer", and "colorectal cancer" combined with "surgery", "chemotherapy", "immunotherapy", "radiation", and combined with "complication", "microbiome", "microbiota", "16S rRNA", "metagenomic" and "nextgeneration sequencing" were used. Since there are few data on the microbiome of patients with colorectal cancer and radiation, and to give an overview of possible complications, additional data from cancer patients (prostate and cervical) who received pelvic radiation were used here. The main search period was from 2010 to July 2021. In the first step, suitable papers were selected by screening their abstracts, and if the content was suitable, the full text was examined. Papers not dealing with microbiome-associated complications related to gastrointestinal-carcinoma therapy were excluded. As a result, 36 papers were included in analysis (Table 1). All clinical data were entered into an electronic database (Excel 2017, Microsoft Corp., Redmond, WA, USA). 


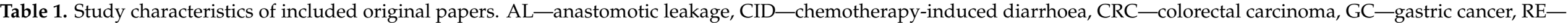
radiation enteropathy, RCT—randomized control trial, SSI—surgical site infection.

\begin{tabular}{|c|c|c|c|c|c|c|}
\hline Author & Year & $\begin{array}{c}\text { Study } \\
\text { Characteristics }\end{array}$ & Population & Sample Type & Methods & Results \\
\hline $\begin{array}{c}\text { Liu, X } \\
\text { et al. [19] }\end{array}$ & 2019 & $\begin{array}{l}\text { Retrospective } \\
\text { cohort trial }\end{array}$ & Human & $\begin{array}{l}\text { Gastric and } \\
\text { tumoral tissue }\end{array}$ & $\begin{array}{l}\text { - } 276 \text { patients with gastric cancer without } \\
\text { neoadjuvant chemotherapy who } \\
\text { received surgery } \\
\text { microbial diversity between normal (230) vs. } \\
\text { Peritumoral (247) vs. tumoral (229) tissue }\end{array}$ & 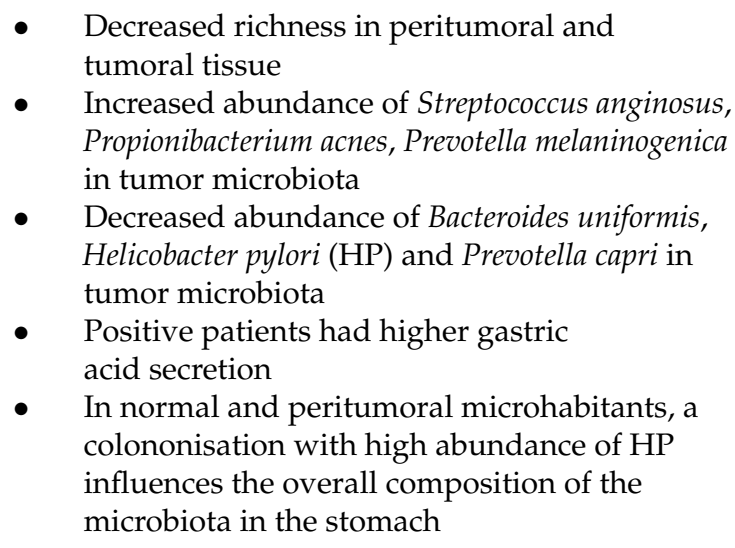 \\
\hline $\begin{array}{l}\text { Sinha, R. } \\
\text { et al. [20] }\end{array}$ & 2016 & Case-control trial & Human & Stool samples & $\begin{array}{l}42 \text { samples from CRC patients vs. } 89 \text { matched } \\
\text { controls (elective surgery but no cancer or } \\
\text { gastrointestinal conditions) }\end{array}$ & $\begin{array}{l}\text { - Higher abundance of Fusobacterium and } \\
\text { Porphyromonas in CRC } \\
\text { Lower abundance of Clostridia, } \\
\text { Lachnospiraceae in CRC }\end{array}$ \\
\hline $\begin{array}{l}\text { Okazaki M. } \\
\text { et al. [21] }\end{array}$ & 2013 & $\mathrm{RCT}$ & Human & Stool samples & $\begin{array}{l}\text { - } \quad 48 \text { patients over } 70 \text { years who received surgery } \\
\text { - } \quad \text { group: synbiotic therapy } 7 \text { days preoperative } \\
\text { and } 10 \text { days postoperative ( } 25 \text { patients) } \\
\text { - C group: no synbiotic therapy ( } 23 \text { patients) }\end{array}$ & $\begin{array}{l}\text { - More short-chain fatty acids and lower } \mathrm{pH} \text { in } \\
\text { the S group } \\
\text { S group: lower abundance of } \\
\text { Enterobacteriaceae, Pseudomonas and } \\
\text { Staphylococcus and stable abundance of } \\
\text { Bifidobacterium and Lactobacillus } \\
\text { Postoperative infections: S group }(12 \%) \text { vs. C } \\
\text { group }(36 \%)(p=0.06)\end{array}$ \\
\hline
\end{tabular}


Table 1. Cont.

\begin{tabular}{|c|c|c|c|c|c|c|}
\hline Author & Year & $\begin{array}{c}\text { Study } \\
\text { Characteristics }\end{array}$ & Population & Sample Type & Methods & Results \\
\hline $\begin{array}{l}\text { Kong, C. } \\
\text { et al. [22] }\end{array}$ & 2019 & Observational trial & Human & Stool samples & $\begin{array}{l}\text { - } \quad 43 \text { CRC patients who received surgery and } \\
\text { adjuvant chemotherapy }\end{array}$ & $\begin{array}{l}\text { - Adjuvant chemotherapy alters the intestinal } \\
\text { microbiota with higher abundance of } \\
\text { pathogenic bacteria } \\
\text { - After surgery, higher abundance of Veillonella, } \\
\text { Morganella, Streptococcus, Proteus, } \\
\text { Escherichia/Shigella, Blautia and } \\
\text { Enterobacteriaceae } \\
\text { - After surgery, lower abundance of Bacillus, } \\
\text { Bilophila, Enterococcus and Barnesiella }\end{array}$ \\
\hline $\begin{array}{l}\text { Deng, X. } \\
\text { et al. [23] }\end{array}$ & 2018 & Control trial & Human & Stool samples & $\begin{array}{ll}\text { - } & 69 \text { patients } \\
\text { - } & \text { Group C: healthy individuals (33) } \\
\text { - } & \text { proup I: samples before treatment of CRC } \\
\text { - } & \text { Group IO: surgically treated CRC patients (5) } \\
\text { - } & \text { Group D: chemotherapeutically treated CRC } \\
& \text { patients (14) }\end{array}$ & $\begin{array}{l}\text { - Reduced alpha-diversity in surgically } \\
\text { treated patients } \\
\text { Higher abundance of Fusobacterium nucleatum, } \\
\text { Veillonella dispar and Sutterella in } \\
\text { chemotherapeutically treated patients -> } \\
\text { potential chemoresistance }\end{array}$ \\
\hline $\begin{array}{c}\text { van Praagh, } \\
\text { J.B. } \\
\text { et al. [25] }\end{array}$ & 2019 & Control trial & Human & Colorectal tissue & - $\quad 122$ patients who received colorectal surgery & $\begin{array}{l}\text { Development of AL was associated with a high } \\
\text { abundance of Bacteroidaceae and } \\
\text { Lachnospiraceae and a low alpha-diversity in } \\
\text { patients with a non-C-seal anastomosis } \\
\text { - AL rates were higher in C-seal anastomosis } \\
\text { patients (25\% vs. } 17 \%) \\
\text { Patients with C-seal anastomosis and AL had } \\
\text { lower abundance of Prevotella oralis }\end{array}$ \\
\hline
\end{tabular}


Table 1. Cont.

\begin{tabular}{|c|c|c|c|c|c|c|}
\hline Author & Year & $\begin{array}{c}\text { Study } \\
\text { Characteristics }\end{array}$ & Population & Sample Type & Methods & Results \\
\hline $\begin{array}{l}\text { Mima, K. } \\
\text { et al. [26] }\end{array}$ & 2020 & Observational trial & Human & Colorectal tissue & $\begin{array}{l}256 \text { samples from patients with } \\
\text { colorectal cancer }\end{array}$ & $\begin{array}{l}\text { - Tissue with higher abundance of Bifidobacterium } \\
\text { genus had an increased risk for AL } \\
\text { (multivariable odds ratio 3.96) } \\
\text { - No association of AL and a high abundance of } \\
\text { Fusobacterium nucleatum, Enterococcus faecalis } \\
\text { and Escherichia coli }\end{array}$ \\
\hline $\begin{array}{l}\text { Schmitt, } \\
\text { F.C.F. } \\
\text { et al. [27] }\end{array}$ & 2021 & Control trial & Human & Stool samples & $\begin{array}{l}\text { - } \quad 62 \text { patients with colorectal cancer } \\
\text { - } 30 \text { patients with postoperative complications vs. } \\
32 \text { without postoperative complications }\end{array}$ & $\begin{array}{l}\text { - Reduced alpha diversity in patients with } \\
\text { postoperative complications, and did not reach } \\
\text { their preoperative microbiota composition even } \\
\text { after } 24 \text { months after surgery } \\
\text { Significant altered microbiome in patients with } \\
\text { postoperative complications } 6 \text { month after } \\
\text { surgery compared to their preoperative } \\
\text { baseline -> associated with long-lasting higher } \\
\text { abundance of Fusobacterium ulcerans }\end{array}$ \\
\hline $\begin{array}{l}\text { Ohigashi, S. } \\
\text { et al. [28] }\end{array}$ & 2013 & Observational trial & Human & Stool samples & $\begin{array}{l}\text { - } 81 \text { patients with colorectal cancer (comparison } \\
\text { of the preoperative and } \\
\text { postoperative microbiota) }\end{array}$ & $\begin{array}{l}\text { - Lower amounts of short-chain fatty acids } \\
\text { after surgery } \\
\text { Postoperative higher abundance of } \\
\text { Enterobacteriaceae, Pseudomonas, Staphylococcus } \\
\text { and Enterococcus } \\
\text { Postoperative decreased abundance of obligate } \\
\text { anaerobs like Clostridium coccoides group, } \\
\text { Bacteroides fragilis group, Prevotella, Atopobium } \\
\text { group, Clostridium leptum subgroup and } \\
\text { Bifidobacterium and lower total bacterial counts }\end{array}$ \\
\hline $\begin{array}{l}\text { Holder- } \\
\text { Murray, J. } \\
\text { et al. [29] }\end{array}$ & 2020 & Observational trial & Human & $\begin{array}{l}\text { Stool samples and } \\
\text { skin tissue }\end{array}$ & - 60 patients who receive colorectal surgery & $\begin{array}{l}\text { Decreased alpha-diversity of the skin at the } \\
\text { - } \\
\text { One patient with a higher abundance of } \\
\text { Enterococcus received a wound infection } \\
\text { At the surgical site was a transient } \\
\text { postoperative loss of Propionibacterium } \\
\text { and Corynebacterium }\end{array}$ \\
\hline
\end{tabular}


Table 1. Cont.

\begin{tabular}{|c|c|c|c|c|c|c|}
\hline Author & Year & $\begin{array}{c}\text { Study } \\
\text { Characteristics }\end{array}$ & Population & Sample Type & Methods & Results \\
\hline $\begin{array}{l}\text { Shogan, B.D. } \\
\text { et al. [30] }\end{array}$ & 2020 & Observational trial & Human & Rectal sample & $\begin{array}{l}101 \text { patients who received colon or } \\
\text { rectal surgery }\end{array}$ & $\begin{array}{l}\text { Significant altered microbiome between the } \\
\text { preoperative and postoperative samples in } \\
\text { patients with postoperative ileus compared to } \\
\text { patients who returned to normal } \\
\text { bowel function } \\
\text { higher abundance of Bacteroides spp., } \\
\text { Ruminococcus spp. and Parabacteroides spp. in } \\
\text { patients with postoperative ileus } \\
\text { patients with SSI or AL had no difference in } \\
\text { their microbiome }\end{array}$ \\
\hline $\begin{array}{l}\text { Liu, Y. } \\
\text { et al. [31] }\end{array}$ & 2018 & Observational trial & Human & Oesophageal tissue & $\begin{array}{l}\text { - } 45 \text { patients with oesophageal carcinoma and } \\
\text { oesophageal resection }\end{array}$ & $\begin{array}{l}\text { - Patients with lymph-node metastasis had } \\
\text { higher abundance of Firmicutes, Bacteroidetes, } \\
\text { Spirochaetes and genera Prevotella and } \\
\text { Treponema, and lower abundance } \\
\text { of Proteobacteria } \\
\text { Patients with T3-4 stage oesophageal } \\
\text { carcinoma had higher abundance of } \\
\text { Streptococcus compared to T1-2 } \\
\text { Multivariant analysis showed unfavourable } \\
\text { survival with combined high abundance of } \\
\text { Streptococcus and Prevotella }\end{array}$ \\
\hline $\begin{array}{l}\text { Liang, W. } \\
\text { et al. [32] }\end{array}$ & 2019 & Control trial & Human & Stool samples & $\begin{array}{l}\text { - } 20 \text { patients with GC and surgery vs. } \\
22 \text { healthy controls }\end{array}$ & $\begin{array}{l}\text { - Compared to healthy individuals the patients } \\
\text { with GC had lower abundance of Bacteroides } \\
\text { and higher abundance of Escherichia/Shigella, } \\
\text { Veillonella and Clostridium XVIII } \\
\text { GC patients had higher abundance of Dialister, } \\
\text { Escherichia/Shigella, Prevotella and Akkermansia } \\
\text { after their surgery compared to the } \\
\text { preoperative samples }\end{array}$ \\
\hline
\end{tabular}


Table 1. Cont.

\begin{tabular}{|c|c|c|c|c|c|c|}
\hline Author & Year & $\begin{array}{c}\text { Study } \\
\text { Characteristics }\end{array}$ & Population & Sample Type & Methods & Results \\
\hline $\begin{array}{l}\text { Reddy, R.M. } \\
\text { et al. [33] }\end{array}$ & 2018 & Observational trial & Human & $\begin{array}{c}\text { Oral saliva, } \\
\text { oesophageal and } \\
\text { gastric tissue, neck } \\
\text { swab or } \\
\text { sputum samples }\end{array}$ & $\begin{array}{l}55 \text { patients which received transhiatal } \\
\text { esophagectomy (51 patients had a carcinoma) }\end{array}$ & $\begin{array}{l}\text { - No correlation between the gastrointestinal } \\
\text { microbiome and the carcinoma } \\
\text { Patients with anastomotic leakage after } \\
\text { esophagectomy correlates with higher variance } \\
\text { in the preoperative microbiome of the stomach } \\
\text { and the oral cavity }\end{array}$ \\
\hline $\begin{array}{l}\text { Shuwen, H. } \\
\text { et al. [35] }\end{array}$ & 2020 & Control trial & Human & Stool samples & $\begin{array}{l}\text { - } 11 \text { CRC patients treated with chemotherapy } \\
\text { (FOLFIRI) vs 15 CRC patients treated with } \\
\text { chemotherapy (XELOX) and after surgery vs. } \\
\text { CRC patients without chemotherapy or surgery }\end{array}$ & $\begin{array}{l}\text { - CRC patients treated with XELOX } \\
\text { chemotherapy had higher abundance of } \\
\text { Humicola, Veillonella, Tremellomycetes } \\
\text { and Malassezia } \\
\text { CRC patients treated with FOLFIRI } \\
\text { chemotherapy had lower abundance of } \\
\text { Clostridiales, Phascolarctobacterium, Humicola, } \\
\text { Faecalibacterium and Rhodotorula and higher } \\
\text { abundance of Dipodascaceae, Tremellomycetes, } \\
\text { Candida, Magnusiomyces, Saccharomycetals, } \\
\text { Lentinula and Malassezia } \\
\text { If patients treated with FOLFIRI chemotherapy } \\
\text { received additionally cetuximab, higher } \\
\text { abundance of Candida, Tremellomycetes, } \\
\text { Lentinula, Malassezia, Dipodascaceae, and } \\
\text { Saccharomycetales, and lower abundance of } \\
\text { Rhodoturola, Magnusiomycetes and Humicola } \\
\text { were found compared to patients treated with } \\
\text { FOLFIRI chemotherapy alone }\end{array}$ \\
\hline $\begin{array}{c}\text { Lu, L. } \\
\text { et al. [36] }\end{array}$ & 2019 & $\begin{array}{l}\text { Retrospective } \\
\text { cohort trial }\end{array}$ & Human & - & $\begin{array}{l}147 \text { patients with metastatic colorectal cancer } \\
\text { (mCRC) who were treated with bevacizumab } \\
\text { (association between outcome and } \\
\text { antibiotic use) }\end{array}$ & $\begin{array}{l}\text { - Patients with } \mathrm{mCRC} \text { treated with bevacizumab } \\
\text { and received a longer period of antibiotics } \\
\text { could be associated with a better outcome }\end{array}$ \\
\hline
\end{tabular}


Table 1. Cont.

\begin{tabular}{|c|c|c|c|c|c|c|}
\hline Author & Year & $\begin{array}{c}\text { Study } \\
\text { Characteristics }\end{array}$ & Population & Sample Type & Methods & Results \\
\hline $\begin{array}{l}\text { Yu, T. } \\
\text { et al. [37] }\end{array}$ & 2017 & Control trial & $\begin{array}{l}\text { Mouse and } \\
\text { cell lines } \\
\text { and } \\
\text { bacterial } \\
\text { Strains, and } \\
\text { human }\end{array}$ & Numerous & $\begin{array}{l}\text { - } 48 \text { CRC patients with recurrence (tissue) vs. } 44 \\
\text { CRC patients without recurrence } \\
\text { - } \quad \text { Cultivation of numerous bacterial strains } \\
\text { - } \quad \text { oxalipliation of numerous cell lines, some with } \\
\text { Numerous mouse models with injected } \\
\text { Fusobacterium nucleatum and some models } \\
\text { with different doses of oxaliplatin treatment }\end{array}$ & $\begin{array}{l}\text { - After a chemotherapy a colorectal carcinoma } \\
\text { recurrence is associated with parcticular } \\
\text { abundant bacteria } \\
\text { CRC patients may benefit to treat Fusobacterium } \\
\text { nucleatum colonisation in terms of management } \\
\text { and prognosis }\end{array}$ \\
\hline $\begin{array}{l}\text { Yan, X. } \\
\text { et al. [38] }\end{array}$ & 2017 & Control trial & Human & Colorectal tissue & $\begin{array}{l}\text { - } 280 \text { Stage III/IV CRC patients } \\
\text { underwent surgery } \\
\text { - Comparison of tumor vs. adjacent } \\
\text { normal tissue }\end{array}$ & $\begin{array}{l}\text { - Tumour stage, lymph node and distant } \\
\text { metastasis correlated with high abundance of } \\
\text { Fusobacterium nucleatum } \\
\text { - Fusobacterium nucleatum further was } \\
\text { independent adverse prognostic factor } \\
\text { for survivial } \\
\text { - CRC patients with lower abundance of } \\
\text { Fusobacterium nucleatum benefit more than CRC } \\
\text { patients with higher abundance of } \\
\text { Fusobacterium nucleatum in terms of } \\
\text { adjuvant chemotherapy }\end{array}$ \\
\hline $\begin{array}{l}\text { Fei, Z. } \\
\text { et al. [13] }\end{array}$ & 2019 & Control trial & Human & Stool samples & $\begin{array}{l}\text { - } 4 \text { stage III CRC patients with CID vs. } 13 \text { stage } \\
\text { III CRC patients without CID } \\
\text { all included patients received CapeOx } \\
\text { chemotherapy (capecitabine and oxaliplatin) }\end{array}$ & $\begin{array}{l}\text { - } \quad \text { Lower diversity and richness in patients } \\
\text { with CID } \\
\text { - Higher abundance of Klebsiella pneumoniae in } \\
\text { stage III CRC patients and CID }\end{array}$ \\
\hline $\begin{array}{l}\text { Zhang, S. } \\
\text { et al. [39] }\end{array}$ & 2019 & $\begin{array}{l}\text { Control trial (mice } \\
\text { were randomized) }\end{array}$ & $\begin{array}{l}\text { Cell lines } \\
\text { (human and } \\
\text { mouse) }\end{array}$ & $\begin{array}{l}\text { Cell lines and } \\
\text { CRC tissue }\end{array}$ & $\begin{array}{l}\text { - Study of the expressed genes induced by } \\
\text { Fusobacterium nucleatum in CRC cell lines } \\
\text { - } 20 \text { mice in } 4 \text { groups for different experiments }\end{array}$ & $\begin{array}{l}\text { - Fusobacterium nucleatum induced the expression } \\
\text { of the BIRC3 gene } \\
\text { higher 5-FU chemoresistance of CRC cell lines } \\
\text { infected with Fusobacterium nucleatum } \\
\text { - High abundance of Fusobacterium nucleatum in } \\
\text { CRC patients after radical surgery who } \\
\text { received 5-FU chemotherapy }\end{array}$ \\
\hline
\end{tabular}


Table 1. Cont.

\begin{tabular}{|c|c|c|c|c|c|c|}
\hline Author & Year & $\begin{array}{c}\text { Study } \\
\text { Characteristics }\end{array}$ & Population & Sample Type & Methods & Results \\
\hline $\begin{array}{l}\text { Yamamura, K. } \\
\text { et al. [40] }\end{array}$ & 2016 & Control trial & Human & $\begin{array}{l}\text { Oesophageal } \\
\text { cancer tissue }\end{array}$ & $\begin{array}{l}\text { - } 325 \text { esophageal cancer patients } \\
\text { underwent surgery } \\
\text { - } 74 \text { esophageal cancer patients with } \\
\text { Fusobacterium nucleatum positiv tissue vs. } 251 \\
\text { esophageal cancer patients with Fusobacterium } \\
\text { nucleatum negativ tissue }\end{array}$ & $\begin{array}{l}\text { - Tumour stage was associated with } \\
\text { Fusobacterium nucleatum }\end{array}$ \\
\hline $\begin{array}{l}\text { Wang, C. } \\
\text { et al. [42] }\end{array}$ & 2018 & RCT & $\begin{array}{l}\text { Mouse cell } \\
\text { lines }\end{array}$ & $\begin{array}{l}\text { Colon tissue and } \\
\text { stool samples }\end{array}$ & $\begin{array}{l}\text { - } 50 \text { mice } \\
10 \text { healthy mice without CRC vs. } 10 \text { CRC mice } \\
\text { without treatment vs. } 10 \text { CRC mice treated with } \\
5 \text {-FU vs. } 10 \text { CRC mice treated with } 50 \mathrm{mg}^{*} \mathrm{~kg}-1 \\
\text { carboxmethylated pachyman }(\mathrm{CMP})+5 \text {-FU vs. } \\
10 \mathrm{CRC} \text { mice treated with } 100 \mathrm{mg}^{*} \mathrm{~kg}-1 \\
\mathrm{CMP}+5-\mathrm{FU}\end{array}$ & $\begin{array}{l}\text { - } \quad \text { Lower alpha diversity in the CRC mice } \\
\text { compared to the healthy group } \\
\text { CRC mice had higher abundance of Firmicutes } \\
\text { and Preoteobacteria and lower abundance of } \\
\text { Bacteroides compared to the healthy group } \\
\text { Higher alpha diversity in CRC mice treated } \\
\text { with 5-FU and CMP compared to CRC mice } \\
\text { treated only with 5-FU } \\
\text { Combination of CMP with 5-FU rever reversed } \\
\text { the shortening of the intestine }\end{array}$ \\
\hline $\begin{array}{l}\text { Wei, Z. } \\
\text { et al. [43] }\end{array}$ & 2017 & Control trial & Human & Jejunum tissue & $\begin{array}{l}\text { - } \quad 90 \text { GC patients underwent surgery } \\
60 \text { patients underwent srugery (SURG group) } \\
\text { vs. } 30 \text { patients underwent neoadjuvant } \\
\text { chemotherapy and surgery (NACT group) }\end{array}$ & $\begin{array}{l}\text { - In the NACT group, more infectious } \\
\text { complications (disrupted tight junctions, } \\
\text { downregulated claudin-1, ZO-1 and occludin) } \\
\text { - } \quad \text { Decreased alpha diversity in NACT group } \\
\text { Lower abundance of Ruminococcus, } \\
\text { Faecalibacterium and Bifidobacterium in } \\
\text { NACT group }\end{array}$ \\
\hline
\end{tabular}


Table 1. Cont.

\begin{tabular}{|c|c|c|c|c|c|c|}
\hline Author & Year & $\begin{array}{c}\text { Study } \\
\text { Characteristics }\end{array}$ & Population & Sample Type & Methods & Results \\
\hline $\begin{array}{l}\text { Golkhalkhali, } \\
\text { B. et al. [44] }\end{array}$ & 2018 & $\mathrm{RCT}$ & Human & Blood samples & $\begin{array}{l}\text { - } 140 \text { CRC patients on XELOX chemotherapy } \\
\text { (capecitabine and oxaliplatin) } \\
\text { - } 70 \text { CRC patients received microbial cell } \\
\text { preperation (MCP) and omega-3 fatty acids vs. } \\
70 \text { CRC patients received placebo }\end{array}$ & $\begin{array}{l}\text { - Fewer side effects of chemotherapy and } \\
\text { improved quality of life in the } \\
\text { intevention group } \\
\text { - } \\
\text { Rising levels of TNF-alpha and IL-6 in the } \\
\text { placebo group } \\
\text { - Reduced IL-6 levels in the intervention group }\end{array}$ \\
\hline $\begin{array}{c}\text { Reis } \\
\text { Ferreira, M. } \\
\text { et al. [46] }\end{array}$ & 2019 & Control trial & Human & $\begin{array}{l}\text { Stool samples and } \\
\text { intestinal mucosa }\end{array}$ & $\begin{array}{l}\text { - } 134 \text { prostate cancer patients after radiation } \\
32 \text { patients assesed for early radiation } \\
\text { enteropathy vs. } 87 \text { patients assesed for late } \\
\text { radiation enteropathy vs. } 9 \text { prostate cancer } \\
\text { patients with radiation therapy received a } \\
\text { coloscopy vs. } 6 \text { healthy controls who received } \\
\text { a coloscopy }\end{array}$ & $\begin{array}{l}\text { - Patients with a higher alpha diversity before } \\
\text { radiation therapy had no symptoms } \\
\text { of enteropathy } \\
\text { - Higher abundance of Roseburia, } \\
\text { Phascolarctobacterium and Clostridium IV in } \\
\text { patients with radiation enteropathy } \\
\text { - Reduced Interleukins (IL7, IL12/IL23p40, IL15, } \\
\text { IL16) in the intestinal mucosa of patients } \\
\text { suffering from radiation enteropathy }\end{array}$ \\
\hline $\begin{array}{l}\text { Wang, Z. } \\
\text { et al. [47] }\end{array}$ & 2019 & Control trial & Human & Stool samples & $\begin{array}{l}\text { - } 18 \text { cervical-cancer patients (Stages II-IV) } \\
\text { - } 10 \text { patients with RE vs. } 8 \text { patients without RE }\end{array}$ & $\begin{array}{l}\text { Patients suffer from RE had a lower alpha } \\
\text { diversity but higher beta diversity } \\
\text { Lower abundance of Bacteroides and a higher } \\
\text { abundance of Gammaproteobacteria and } \\
\text { Proteobacteria } \\
\text { - Patients with higher richness of Coprococcus } \\
\text { before radiation therapy were more likely to } \\
\text { develop RE } \\
\text { Patients suffering from mild RE had higher } \\
\text { abundance of Alcanivorax and Virgibacillus }\end{array}$ \\
\hline
\end{tabular}




\section{Gastrointestinal-Cancer Therapies and Microbiome}

In gastric cancer, different tumour entities have different compositions of the gastric microbiome [48]. In colorectal carcinoma, there are microbiome changes compared to healthy individuals. In particular, Proteobacteria and Actinobacteria occur more frequently in patients with colorectal carcinoma [20]. In the following sections, we give an overview of the complications and corresponding microbiome for specific therapeutic options. Furthermore, in Figure 1 the key findings are summarized for a better overview.

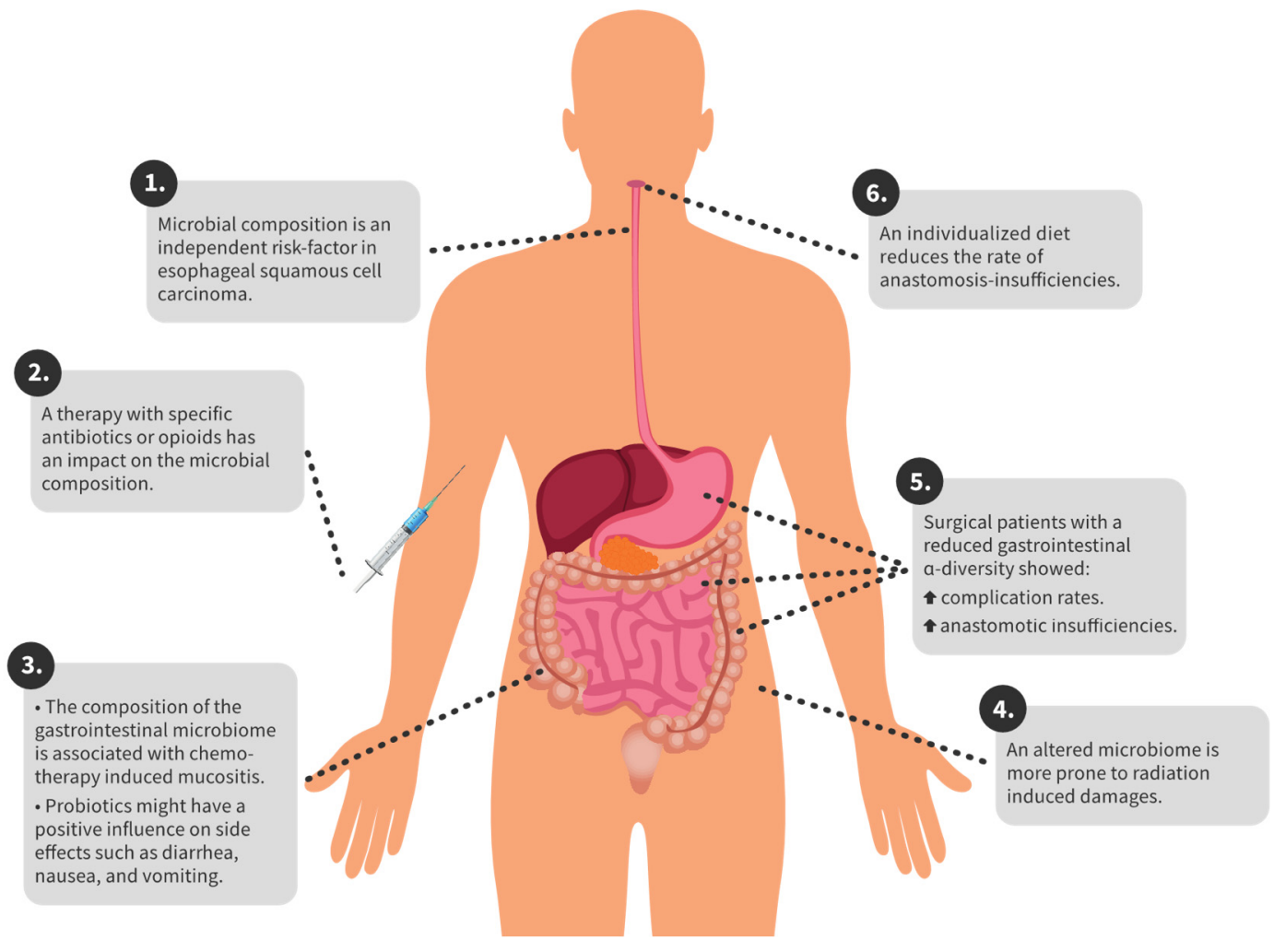

Figure 1. Overview of key findings.

\subsection{Perioperative Complications}

Several studies showed that the microbiome is directly altered after surgery [21-23]. In abdominal surgery, anastomotic insufficiencies and abdominal infections are feared complications that often lead to life-threatening sepsis. The most common complications after colectomy in colorectal-cancer patients are anastomotic leakages $(8.4 \%)$ and wound infection (13.4\%) [49]. Patients with a colorectal carcinoma that showed reduced alpha diversity and a higher abundance of Lachnospiraceae were more prone to anastomotic insufficiencies [24]. A higher abundance of Bacteroidaceae is associated with an increased risk of anastomosis insufficiency [25]. In patients with colorectal carcinoma, abundant Bifidobacterium genus in the colorectal tissue is associated with an increased risk of anastomotic insufficiency [26]. A recent study from 2021 showed that rectal or colonic surgery could impact the microbiome for two years, and even after that time, the baseline was not reached. Diversity in patients with complications was lower than that in patients without complications [27].

After the resection of colorectal carcinoma, Pseudomonas, Enterococcus, Staphylococcus, and Enterobacteriaceae were significantly increased, and short-chain fatty acids (SCFAs) were significantly decreased [28]. Meta-analysis revealed that patients who had gastrointestinal surgery and higher diversity with more beneficial bacteria postoperatively also had a better outcome [50]. One study examined the skin microbiome after colorectal surgery and demonstrated a decrease in alpha diversity [29]. 
A further complication after colorectal surgery can be an ileus. Patients who had suffered a postoperative ileus had a significantly altered gut microbiome compared to patients who returned to normal bowel function [30].

In a study from Asia with 45 patients with oesophageal squamous cell carcinoma, Streptococcus and Prevotella spp. in the oesophageal tissue were independent risk factors for prognosis [31]. Patients with gastric cancer also experience changes in the microbiome during the perioperative period. Compared to the preoperative sample, genera Escherichia/Shigella, Akkermansia, Dialister, and Lactobacillus were more abundant [32].

In patients with gastric carcinoma, a shift in the gut microbiome was demonstrated in the perioperative setting. Thus, patients had fewer Bacteroides, and more Escherichia/Shigella, Clostridium, and Veillonella than healthy individuals did after gastrectomy. Patients also had a nonsignificant decrease in short-chain fatty acids in their stool after gastrectomy [32]. Furthermore, a more similar microbiome (lower beta diversity) between the oral and gastric microbiomes was associated with a lower risk of anastomotic leak after oesophageal resection [33].

\subsection{Complications during Chemo- and Immunotherapy}

Patients who suffer from gastrointestinal cancer often receive adjuvant or neoadjuvant chemotherapy, which alters the gut microbiome [35]. A retrospective study showed that patient outcomes can be improved during immunotherapy with bevacizumab using antibiotics. Patients with metastatic colorectal carcinoma had lower mortality rates if treated with antibiotics for a more extended period [36]. Another study showed that Fusobacterium nucleatum was abundant in colorectal-carcinoma patients with recurrence after chemotherapy. This study showed that F. nucleatum controls the Toll-like receptor, microRNA, and autophagy network, thus influencing cancer chemoresistance [37]. Among others, the Fusobacterium nucleatum bacterium is associated with a reduced response to chemotherapy [23,38].

Chemotherapy CapeOx includes capecitabine plus oxaliplatin. A study by Kong et al. showed that surgery and CapeOx chemotherapy significantly altered the gut microbiome, and may lead to an abundance of pathogenic bacteria [22]. Similar results were obtained in a study investigating chemotherapy-induced diarrhoea (CID) in patients with Stage III colorectal cancer after CapeOx chemotherapy and surgery. Here, a dysbiosis of the intestinal microbiome was found in CID patients compared to patients without CID. Among others, Klebsiella pneumoniae was most frequently detected in CID patients [13].

Another problem is the resistance of tumour cells to 5-fluorouracil (5-FU). Fusobacterium nucleatum also seems to play a role here by upregulating the expression of BIRC3 in tumour cells, thereby causing them to become insensitive to 5-FU [39]. In addition, Fusobacterium nucleatum is associated with oesophageal squamous cell carcinoma and cancer-specific survival [40], whereas probiotics, including Bifidobacterium bifidum, improve the outcome of 5-FU chemotherapy in rats with chemically induced colorectal cancer by enhancing the antitumour effect [41]. Carboxymethyl pachyman (CMP) is a polysaccharide that has anti-inflammatory and immune regulatory effects. In colorectal-carcinoma mice treated with 5-FU, the additional administration of CMP restored the diversity of the gut microbiome [42]. In patients with advanced gastric cancer, patients who had received neoadjuvant chemotherapy before surgery also had increased postoperative infections. Lower diversity and reduced Bifidobacterium, Faecalibacterium, and Ruminococcus in patients with postoperative infections were detected [43]. The next step is to modify the effects of Fusobacterium nucleatum to improve patient outcomes. A first study addressed this goal and demonstrated that Paris polyphyla, a herbal medicine, could inhibit both colorectal-cancer and Fusobacterium nucleatum growth in human colorectal-cancer cell lines [51].

Another complication of chemotherapy is mucositis, which is a dose-limiting factor. Thus, mucositis seems to be a complex interplay among the intestinal microbiome, the host cells, and the intestinal microenvironment. Unfortunately, only bacteria that promote mucositis, such as Enterobacteriaceae, and no protective bacteria were identified so far [52]. 
The administration of probiotics and omega- 3 fatty acids in an RCT study of 140 patients benefited quality of life and side effects such as diarrhoea, nausea, and vomiting [44].

\subsection{Complications during Radiotherapy}

Radiotherapy can form part of the therapy against cancer. Complications associated with the patient's intestinal microbiome may occur. In a study of patients with both colorectal adenoma and carcinoma, no difference was shown between patients who received surgery alone and patients who received chemotherapy or chemotherapy with radiation. However, the group of patients with colorectal carcinoma who received chemotherapy and radiation consisted of only 5 patients [45]. Thus, significantly more Clostridium IV, Pascolarctobacterium, and Roseburia were detected in prostate-cancer patients with radiation enteropathy. In addition, lower diversity was associated with radiation enteropathy [46]. Similar results were obtained in a study from 2019, which showed that cervical-cancer patients suffering from radiation enteritis had enriched Coprococcus in their gut microbiome before therapy. Patients suffering from radiation enteritis also had dysbiosis and lowered alpha diversity. At the same time, a lower abundance of Bacteroides, and a higher abundance of Gammaproteobacteria and Proteobacteria were present in patients with radiation enteritis [47].

\section{Discussion}

The microbiome impacts all therapeutic options in gastrointestinal carcinoma. It can influence the outcome of patients undergoing chemotherapy or immunotherapy and severely limit the wellbeing of patients who have undergone radiotherapy and suffer from mucositis or enteritis. Patients with decreased gut microbiome diversity show higher associated complication rates [53]. Furthermore, side effects can lead to dose limiting during chemotherapy. To adequately appreciate these effects in clinical practice, assessing the type of therapy and the underlying microbiome is crucial. Thus, classical therapy options could be adapted to the individual microbiome, and improve outcomes and quality of life during therapy.

The optimisation of the gut microbiome impacts complications. Enterococcus faecalis is associated with an increased rate of anastomosis insufficiency, and second- and thirdgeneration cephalosporins failed to eradicate E. faecalis from anastomotic tissue [54]. In addition, there was a positive effect on anastomosis healing by a low-fat/high-fibre diet in a murine model, which was attributed, among other things, to an improved diversity of the intestinal microbiome [55]. The positive effect of SCFAs was also demonstrated in animal models. With the administration of SCFAs, the strength of anastomosis could be significantly increased compared to in the group that did not receive SCFAs $[56,57]$. In a mouse model, an altered gut microbiome could also lead to surgical-site infection. Surgical-site infection could be caused by the spread of bacteria by immune cells [58]. Whether therapy with probiotics can positively influence surgical-site infections is not yet conclusively clarified [59]. According to the ERAS protocol, patients who had received perioperative immunonutritrion had significantly fewer infectious complications, such as surgical-site infections [60]. In addition, next-generation sequencing can help to identify culture-negative surgical-site infections [61].

Firmicutes/Bacteroides ratio (F/B ratio) is also a well-studied marker for dysbiosis, and is altered during the treatment of gastrointestinal carcinoma. If the F/B ratio of intensive-care patients is $<0.1$ or $>10$, they have a poorer outcome [62]. Thus, patients who had received pelvic radiation, including for colorectal or anal carcinoma, experienced radiation-induced diarrhoea with an increased $\mathrm{F} / \mathrm{B}$ ratio and dysbiosis compared with patients who did not experience diarrhoea [63]. Thus, a goal of future therapy is that the $\mathrm{F} / \mathrm{B}$ ratio improves again after treatment. For example, the $\mathrm{F} / \mathrm{B}$ ratio is increased in obesity [64,65]. At the same time, sport leads to a reduction in F/B ratio [66]. Whether exercise also positively impacts complication rates in the therapy of gastrointestinal carcinoma is unknown. However, no studies demonstrated any effect on the F/B ratio in 
dysbiosis [12,67]. The extent to which the F/B ratio is also an indicator of dysbiosis in the treatment of gastrointestinal carcinoma remains to be investigated.

One way to reduce complications is to actively influence the microbiome. Probiotics are beneficial bacteria that have a positive effect on the gut microbiome. In comparison, prebiotics are dietary fibres that help beneficial bacteria to grow. Synbiotics consist of prebiotics and probiotics. A study with colorectal-carcinoma patients who had undergone surgery and received probiotics showed that they had significantly fewer days to their first postoperative defecation and flatus than the placebo group did. Diarrhoea was also less frequent in the probiotic treatment group [68]. In a cohort with 46 patients undergoing resection for periampullary neoplasm, a significant reduction in mortality, duration of antibiotic therapy, length of hospital stays, infections, and postoperative complications was shown with the administration of synbiotics [69]. A review investigated the effect of probiotics and synbiotics in colorectal patients undergoing surgery. There were significantly less severe diarrhoea, postoperative infections, chemotherapy side effects, and a shorter duration of antibiotic therapy in patients treated with probiotics or synbiotics [70]. In the colorectal-carcinoma mouse model, probiotics containing Pediococcus pentosaceus inhibit tumour growth and modulate gut microbiome dysbiosis towards eubiosis [71]. Cochrane analysis could not demonstrate a relevant effect of probiotics on radiotherapyor chemotherapy-induced diarrhoea [72].

Numerous factors can influence the microbiome, e.g., diet, obesity, and physical activity. An increased BMI during laparoscopic colorectal-cancer surgery [73] and preoperative obesity is associated with poorer outcomes. On the other hand, early oral nutrition and thereby a more physiological gastrointestinal microbiome are associated with better outcomes [74]. After gastrectomy, $41.5 \%$ of patients suffer from sarcopenia, which highlights the importance of a sufficient nutritional status [75]. That diet and nutritional status affect the microbiome also shows that decreased secondary bile acids in the gut are a reasonable basis for the growth of Clostridium difficile [76]. A study with mice suffering from multiple sclerosis showed that one hour of strength exercise increased alpha diversity and abundance of the gut microbiota. Additionally, the abundance of short-chain fatty acidproducing bacteria and the F/B ratio were decreased [77]. Whether strength exercise has a similar effect on the microbiome in gastrointestinal carcinoma patients remains unclear.

Another complication of chemotherapy with irinotecan in patients with colorectal carcinoma is diarrhoea. The gut microbiome decomposes irinotecan-metabolite back to the active form, causing side effects. A new therapy, together with apple pectin, was able to inhibit metabolites responsible for diarrhoea in cell culture with human colorectal tumour cells and at the same time enhance the cytotoxic effect of irinotecan [78]. However, nonresponse to chemotherapy may also represent a complication of chemotherapy. New therapeutic approaches try to inhibit the growth of $F$. nucleatum by phage-guided nanotechnology and improve the first-line chemotherapy treatment [79]. Furthermore, the fact that the side effects of chemotherapy are often treated with other drugs should not be ignored. Thus, animal models showed that proton pump inhibitors, opioids, and antipsychotics are associated with dysbiosis [80]. In patients, opioids, and antibiotics such as piperacillin/tazobactam, are associated with alterations of the gut microbiome, and smaller amounts of protective bacteria such as Blautia and Lactobacillus are detectable [81]. Nevertheless, the preoperative administration of oral antibiotics could lead to significantly fewer postoperative complications in elective colorectal surgery than those in mechanical bowel preparation [82].

Another therapeutic option could be faecal microbiota transplant (FMT) to influence the microbiome in patients with gastrointestinal cancer under specific therapies. Currently, data on the effect of FMT in gastrointestinal carcinoma is insufficient. However, animal models showed that, when the FMT donor was a patient with colorectal carcinoma and the FMT recipient mouse was germ-free, intestinal dysplasia and proliferation could be induced [83]. In another colorectal-carcinoma mouse model, oral-faecal microbiota transplantation was performed during five days of FOLFOX chemotherapy and two days 
beyond, $\S$ and compared to mice that did not receive FMT. Mice treated with FMT had less severe diarrhoea and reduced mucositis, and at the same time, it did not induce bacteraemia. In addition, dysbiosis was improved in FMT-treated mice after FOLFOX chemotherapy [84]. The microbiome and health status of the patient can thus be significantly changed by FMT. Whether physiological conditions can also be achieved by FMT is unknown for gastrointestinal carcinoma. However, FMT should not be underestimated, as shown by case reports in which patients had suffered severe complications or died due to FMT [85-88]. Nevertheless, FMT is a promising therapeutic option, but further studies are needed to evaluate it and identify its risks leading to serious side effects.

A feared complication in patients undergoing surgery on the gastrointestinal tract is sepsis, even though these are not specific complications for operations on the gastrointestinal tract. The gut microbiome also interacts with the immune system. Therefore, an altered microbiome cannot be neglected concerning the immune response. This directly influences the mucosal adaptive immunity and immune cells [89]. The microbiome influences the course of sepsis [90]. Patients who have undergone gastrointestinal surgery and suffer from dysbiosis resulting from the procedure may have a worse outcome if they develop sepsis.

Unfortunately, there are currently insufficient data for patients with gastrointestinal carcinoma under radiation and possible complications associated with the microbiome. Therefore, additional studies with prostate- and cervical-cancer patients were presented here. Furthermore, dysbiosis and associated inflammation were found with pelvic radiation in mice, which may be an additional factor for intestinal radiation-induced damage [91].

Furthermore, the microbiota does not only consist of bacteria; viruses and fungi are an additional part of it. The virome as part of the microbiota also impacts outcomes in patients with colorectal cancer. Thus, virome-associated risk groups could be identified [92]. The extent to which individual viruses, fungi, and bacteria affect both the patient and each other must be investigated in more detail.

Another challenge is that the microbiome differs depending on whether a healthy organ or a carcinoma is present, and the type of underlying carcinoma. For example, different microbiomes could be detected between oesophageal squamous cell carcinoma tissue and gastric cardia adenocarcinoma tissue [93]. This was confirmed in a microbiome comparison of a healthy oesophagus, Barrett's oesophagus, an oesophageal squamous cell carcinoma, and oesophageal adenocarcinoma [94].

The microbiome in colorectal carcinoma is better studied compared to oesophageal and gastric carcinomas. So far, data for oesophageal and gastric carcinomas are limited regarding perioperative complications and complications during chemotherapy. Thus, only statements about the overall outcome or risk of recurrence with different microbiomes in oesophageal carcinoma have been made so far [31,95].

\section{Conclusions}

Therapeutic options of gastrointestinal carcinoma are surgery, chemo- or immunotherapy, and radiation. Each therapy option can cause different complications, which can be dose-limiting. Through next-generation sequencing, the underlying microbiome during a complication could be studied in more detail. This has allowed for the investigation of risk constellations, such as the presence of abundant Fusobacterium nucleatum during chemotherapy. Unfortunately, to date, only the gut microbiome in colorectal cancer and associated complications has mainly been investigated. Future therapeutic approaches should consider any individual differences in the underlying microbiome. Accordingly, the microbiome during peritherapeutic complications should be further investigated for all gastrointestinal carcinomas.

Author Contributions: Conceptualisation, K.M.T., S.B., M.A.W., and F.C.F.S.; methodology, K.M.T. and F.C.F.S.; validation, K.M.T., S.B., M.A.W., and F.C.F.S.; investigation, K.M.T.; resources, K.M.T.; writing-original draft preparation, K.M.T. and F.C.F.S.; writing-review and editing, K.M.T. and F.C.F.S.; supervision, M.A.W., and S.B.; project administration, F.C.F.S. All authors have read and agreed to the published version of the manuscript. 
Funding: This research received no external funding.

Institutional Review Board Statement: Not applicable.

Informed Consent Statement: Not applicable.

Data Availability Statement: Not applicable.

Conflicts of Interest: The authors declare no conflict of interest.

\section{References}

1. Sender, R.; Fuchs, S.; Milo, R. Revised Estimates for the Number of Human and Bacteria Cells in the Body. PLoS Biol. 2016, 14, e1002533. [CrossRef]

2. Kawanami, T.; Yatera, K.; Yamasaki, K.; Noguchi, S.; Fukuda, K.; Akata, K.; Naito, K.; Kido, T.; Ishimoto, H.; Taniguchi, H.; et al. Clinical impact of methicillin-resistant staphylococcus aureus on bacterial pneumonia: Cultivation and 16S ribosomal RNA gene analysis of bronchoalveolar lavage fluid. BMC Infect. Dis. 2016, 16, 155. [CrossRef]

3. Decker, S.O.; Kruger, A.; Wilk, H.; Grumaz, S.; Vainshtein, Y.; Schmitt, F.C.F.; Uhle, F.; Bruckner, T.; Zimmermann, S.; Mehrabi, A.; et al. New approaches for the detection of invasive fungal diseases in patients following liver transplantation-results of an observational clinical pilot study. Langenbecks Arch. Surg. 2019, 404, 309-325. [CrossRef] [PubMed]

4. Decker, S.O.; Sigl, A.; Grumaz, C.; Stevens, P.; Vainshtein, Y.; Zimmermann, S.; Weigand, M.A.; Hofer, S.; Sohn, K.; Brenner, T. Immune-Response Patterns and Next Generation Sequencing Diagnostics for the Detection of Mycoses in Patients with Septic Shock-Results of a Combined Clinical and Experimental Investigation. Int. J. Mol. Sci. 2017, 18, 1796. [CrossRef] [PubMed]

5. Shanahan, F.; Ghosh, T.S.; O'Toole, P.W. The Healthy Microbiome-What Is the Definition of a Healthy Gut Microbiome? Gastroenterology 2021, 160, 483-494. [CrossRef] [PubMed]

6. Rothschild, D.; Weissbrod, O.; Barkan, E.; Kurilshikov, A.; Korem, T.; Zeevi, D.; Costea, P.I.; Godneva, A.; Kalka, I.N.; Bar, N.; et al. Environment dominates over host genetics in shaping human gut microbiota. Nature 2018, 555, 210-215. [CrossRef]

7. Vangay, P.; Johnson, A.J.; Ward, T.L.; Al-Ghalith, G.A.; Shields-Cutler, R.R.; Hillmann, B.M.; Lucas, S.K.; Beura, L.K.; Thompson, E.A.; Till, L.M.; et al. US Immigration Westernizes the Human Gut Microbiome. Cell 2018, 175, 962-972.e910. [CrossRef]

8. Sanna, S.; van Zuydam, N.R.; Mahajan, A.; Kurilshikov, A.; Vich Vila, A.; Vosa, U.; Mujagic, Z.; Masclee, A.A.M.; Jonkers, D.; Oosting, M.; et al. Causal relationships among the gut microbiome, short-chain fatty acids and metabolic diseases. Nat. Genet. 2019, 51, 600-605. [CrossRef]

9. Morrison, D.J.; Preston, T. Formation of short chain fatty acids by the gut microbiota and their impact on human metabolism. Gut Microbes 2016, 7, 189-200. [CrossRef]

10. Tanaka, M.; Nakayama, J. Development of the gut microbiota in infancy and its impact on health in later life. Allergol. Int. Off. J. Jpn. Soc. Allergol. 2017, 66, 515-522. [CrossRef] [PubMed]

11. Moron, R.; Galvez, J.; Colmenero, M.; Anderson, P.; Cabeza, J.; Rodriguez-Cabezas, M.E. The Importance of the Microbiome in Critically Ill Patients: Role of Nutrition. Nutrients 2019, 11, 3002. [CrossRef] [PubMed]

12. Schmitt, F.C.F.; Brenner, T.; Uhle, F.; Loesch, S.; Hackert, T.; Ulrich, A.; Hofer, S.; Dalpke, A.H.; Weigand, M.A.; Boutin, S. Gut microbiome patterns correlate with higher postoperative complication rates after pancreatic surgery. BMC Microbiol. $2019,19,42$. [CrossRef]

13. Fei, Z.; Lijuan, Y.; Xi, Y.; Wei, W.; Jing, Z.; Miao, D.; Shuwen, H. Gut microbiome associated with chemotherapy-induced diarrhea from the CapeOX regimen as adjuvant chemotherapy in resected stage III colorectal cancer. Gut Pathog. 2019, 11, 18. [CrossRef] [PubMed]

14. Bray, F.; Ferlay, J.; Soerjomataram, I.; Siegel, R.L.; Torre, L.A.; Jemal, A. Global cancer statistics 2018: GLOBOCAN estimates of incidence and mortality worldwide for 36 cancers in 185 countries. CA Cancer J. Clin. 2018, 68, 394-424. [CrossRef] [PubMed]

15. Dejea, C.M.; Fathi, P.; Craig, J.M.; Boleij, A.; Taddese, R.; Geis, A.L.; Wu, X.; DeStefano Shields, C.E.; Hechenbleikner, E.M.; Huso, D.L.; et al. Patients with familial adenomatous polyposis harbor colonic biofilms containing tumorigenic bacteria. Science 2018, 359, 592-597. [CrossRef]

16. Rastogi, Y.R.; Saini, A.K.; Thakur, V.K.; Saini, R.V. New Insights into Molecular Links Between Microbiota and Gastrointestinal Cancers: A Literature Review. Int. J. Mol. Sci. 2020, 21, 3212. [CrossRef]

17. Miyake, T.; Mori, H.; Yasukawa, D.; Hexun, Z.; Maehira, H.; Ueki, T.; Kojima, M.; Kaida, S.; Iida, H.; Shimizu, T.; et al. The Comparison of Fecal Microbiota in Left-Side and Right-Side Human Colorectal Cancer. Eur. Surg. Res. 2021, 1-7. [CrossRef] [PubMed]

18. Kim, K.; Castro, E.J.T.; Shim, H.; Advincula, J.V.G.; Kim, Y.W. Differences Regarding the Molecular Features and Gut Microbiota Between Right and Left Colon Cancer. Ann. Coloproctol. 2018, 34, 280-285. [CrossRef] [PubMed]

19. Liu, H.; Chen, X.; Hu, X.; Niu, H.; Tian, R.; Wang, H.; Pang, H.; Jiang, L.; Qiu, B.; Chen, X.; et al. Alterations in the gut microbiome and metabolism with coronary artery disease severity. Microbiome 2019, 7, 68. [CrossRef] [PubMed]

20. Sinha, R.; Ahn, J.; Sampson, J.N.; Shi, J.; Yu, G.; Xiong, X.; Hayes, R.B.; Goedert, J.J. Fecal Microbiota, Fecal Metabolome, and Colorectal Cancer Interrelations. PLoS ONE 2016, 11, e0152126. [CrossRef] 
21. Okazaki, M.; Matsukuma, S.; Suto, R.; Miyazaki, K.; Hidaka, M.; Matsuo, M.; Noshima, S.; Zempo, N.; Asahara, T.; Nomoto, K. Perioperative synbiotic therapy in elderly patients undergoing gastroenterological surgery: A prospective, randomized control trial. Nutrition 2013, 29, 1224-1230. [CrossRef]

22. Kong, C.; Gao, R.; Yan, X.; Huang, L.; He, J.; Li, H.; You, J.; Qin, H. Alterations in intestinal microbiota of colorectal cancer patients receiving radical surgery combined with adjuvant CapeOx therapy. Sci. China Life Sci. 2019, 62, 1178-1193. [CrossRef] [PubMed]

23. Deng, X.; Li, Z.; Li, G.; Li, B.; Jin, X.; Lyu, G. Comparison of Microbiota in Patients Treated by Surgery or Chemotherapy by 16S rRNA Sequencing Reveals Potential Biomarkers for Colorectal Cancer Therapy. Front. Microbiol. 2018, 9, 1607. [CrossRef] [PubMed]

24. van Praagh, J.B.; de Goffau, M.C.; Bakker, I.S.; Harmsen, H.J.; Olinga, P.; Havenga, K. Intestinal microbiota and anastomotic leakage of stapled colorectal anastomoses: A pilot study. Surg. Endosc. 2016, 30, 2259-2265. [CrossRef] [PubMed]

25. van Praagh, J.B.; de Goffau, M.C.; Bakker, I.S.; van Goor, H.; Harmsen, H.J.M.; Olinga, P.; Havenga, K. Mucus Microbiome of Anastomotic Tissue During Surgery Has Predictive Value for Colorectal Anastomotic Leakage. Ann. Surg. 2019, 269, 911-916. [CrossRef] [PubMed]

26. Mima, K.; Sakamoto, Y.; Kosumi, K.; Ogata, Y.; Miyake, K.; Hiyoshi, Y.; Ishimoto, T.; Iwatsuki, M.; Baba, Y.; Iwagami, S.; et al. Mucosal cancer-associated microbes and anastomotic leakage after resection of colorectal carcinoma. Surg. Oncol. 2020, 32, 63-68. [CrossRef]

27. Schmitt, F.C.F.; Schneider, M.; Mathejczyk, W.; Weigand, M.A.; Figueiredo, J.C.; Li, C.I.; Shibata, D.; Siegel, E.M.; Toriola, A.T.; Ulrich, C.M.; et al. Postoperative Complications Are Associated with Long-Term Changes in the Gut Microbiota Following Colorectal Cancer Surgery. Life 2021, 11, 246. [CrossRef]

28. Ohigashi, S.; Sudo, K.; Kobayashi, D.; Takahashi, T.; Nomoto, K.; Onodera, H. Significant changes in the intestinal environment after surgery in patients with colorectal cancer. J. Gastrointest. Surg. 2013, 17, 1657-1664. [CrossRef]

29. Holder-Murray, J.; Yeh, A.; Rogers, M.B.; Firek, B.; Mahler, B.; Medich, D.; Celebrezze, J.; Morowitz, M.J. Time-dependent displacement of commensal skin microbes by pathogens at the site of colorectal surgery. Clin. Infect. Dis. 2020. [CrossRef] [PubMed]

30. Shogan, B.D.; Chen, J.; Duchalais, E.; Collins, D.; Chang, M.; Krull, K.; Krezalek, M.A.; Larson, D.W.; Walther-Antonio, M.R.; Chia, N.; et al. Alterations of the Rectal Microbiome Are Associated with the Development of Postoperative Ileus in Patients Undergoing Colorectal Surgery. J. Gastrointest. Surg. 2020, 24, 1663-1672. [CrossRef]

31. Liu, Y.; Lin, Z.; Lin, Y.; Chen, Y.; Peng, X.E.; He, F.; Liu, S.; Yan, S.; Huang, L.; Lu, W.; et al. Streptococcus and Prevotella are associated with the prognosis of oesophageal squamous cell carcinoma. J. Med. Microbiol. 2018, 67, 1058-1068. [CrossRef]

32. Liang, W.; Yang, Y.; Wang, H.; Wang, H.; Yu, X.; Lu, Y.; Shen, S.; Teng, L. Gut microbiota shifts in patients with gastric cancer in perioperative period. Medicine (Baltimore) 2019, 98, e16626. [CrossRef]

33. Reddy, R.M.; Weir, W.B.; Barnett, S.; Heiden, B.T.; Orringer, M.B.; Lin, J.; Chang, A.C.; Carrott, P.W.; Lynch, W.R.; Beer, D.G.; et al. Increased Variance in Oral and Gastric Microbiome Correlates With Esophagectomy Anastomotic Leak. Ann. Thorac. Surg. 2018, 105, 865-870. [CrossRef] [PubMed]

34. Kumar, A.; Augustine, D.; Sudhindran, S.; Kurian, A.M.; Dinesh, K.R.; Karim, S.; Philip, R. Weissella confusa: A rare cause of vancomycin-resistant Gram-positive bacteraemia. J. Med. Microbiol. 2011, 60, 1539-1541. [CrossRef] [PubMed]

35. Shuwen, H.; Xi, Y.; Yuefen, P.; Jiamin, X.; Quan, Q.; Haihong, L.; Yizhen, J.; Wei, W. Effects of postoperative adjuvant chemotherapy and palliative chemotherapy on the gut microbiome in colorectal cancer. Microb. Pathog. 2020, 149, 104343. [CrossRef]

36. Lu, L.; Zhuang, T.; Shao, E.; Liu, Y.; He, H.; Shu, Z.; Huang, Y.; Yao, Y.; Lin, S.; Lin, S.; et al. Association of antibiotic exposure with the mortality in metastatic colorectal cancer patients treated with bevacizumab-containing chemotherapy: A hospital-based retrospective cohort study. PLoS ONE 2019, 14, e0221964. [CrossRef] [PubMed]

37. Yu, T.; Guo, F.; Yu, Y.; Sun, T.; Ma, D.; Han, J.; Qian, Y.; Kryczek, I.; Sun, D.; Nagarsheth, N.; et al. Fusobacterium nucleatum Promotes Chemoresistance to Colorectal Cancer by Modulating Autophagy. Cell 2017, 170, 548-563.e516. [CrossRef]

38. Yan, X.; Liu, L.; Li, H.; Qin, H.; Sun, Z. Clinical significance of Fusobacterium nucleatum, epithelial-mesenchymal transition, and cancer stem cell markers in stage III/IV colorectal cancer patients. Onco Targets Ther. 2017, 10, 5031-5046. [CrossRef] [PubMed]

39. Zhang, S.; Yang, Y.; Weng, W.; Guo, B.; Cai, G.; Ma, Y.; Cai, S. Fusobacterium nucleatum promotes chemoresistance to 5-fluorouracil by upregulation of BIRC3 expression in colorectal cancer. J. Exp. Clin. Cancer Res. 2019, 38, 14. [CrossRef] [PubMed]

40. Yamamura, K.; Baba, Y.; Nakagawa, S.; Mima, K.; Miyake, K.; Nakamura, K.; Sawayama, H.; Kinoshita, K.; Ishimoto, T.; Iwatsuki, M.; et al. Human Microbiome Fusobacterium Nucleatum in Esophageal Cancer Tissue Is Associated with Prognosis. Clin. Cancer Res. 2016, 22, 5574-5581. [CrossRef]

41. Genaro, S.C.; Lima de Souza Reis, L.S.; Reis, S.K.; Rabelo Socca, E.A.; Favaro, W.J. Probiotic supplementation attenuates the aggressiveness of chemically induced colorectal tumor in rats. Life Sci. 2019, 237, 116895. [CrossRef]

42. Wang, C.; Yang, S.; Gao, L.; Wang, L.; Cao, L. Carboxymethyl pachyman (CMP) reduces intestinal mucositis and regulates the intestinal microflora in 5-fluorouracil-treated CT26 tumour-bearing mice. Food Funct. 2018, 9, 2695-2704. [CrossRef]

43. Wei, Z.; Tan, B.; Cao, S.; Liu, S.; Tan, X.; Yao, Z.; Yin, N.; Li, J.; Zhang, D.; Zhou, Y. The influence of neoadjuvant chemotherapy on gastric cancer patients' postoperative infectious complications: What is the negative role played by the intestinal barrier dysfunction? Oncotarget 2017, 8, 43376-43388. [CrossRef] [PubMed] 
44. Golkhalkhali, B.; Rajandram, R.; Paliany, A.S.; Ho, G.F.; Wan Ishak, W.Z.; Johari, C.S.; Chin, K.F. Strain-specific probiotic (microbial cell preparation) and omega-3 fatty acid in modulating quality of life and inflammatory markers in colorectal cancer patients: A randomized controlled trial. Asia Pac. J. Clin. Oncol. 2018, 14, 179-191. [CrossRef]

45. Sze, M.A.; Baxter, N.T.; Ruffin, M.T.t.; Rogers, M.A.M.; Schloss, P.D. Normalization of the microbiota in patients after treatment for colonic lesions. Microbiome 2017, 5, 150. [CrossRef] [PubMed]

46. Reis Ferreira, M.; Andreyev, H.J.N.; Mohammed, K.; Truelove, L.; Gowan, S.M.; Li, J.; Gulliford, S.L.; Marchesi, J.R.; Dearnaley, D.P. Microbiota- and Radiotherapy-Induced Gastrointestinal Side-Effects (MARS) Study: A Large Pilot Study of the Microbiome in Acute and Late-Radiation Enteropathy. Clin. Cancer Res. 2019, 25, 6487-6500. [CrossRef] [PubMed]

47. Wang, Z.; Wang, Q.; Wang, X.; Zhu, L.; Chen, J.; Zhang, B.; Chen, Y.; Yuan, Z. Gut microbial dysbiosis is associated with development and progression of radiation enteritis during pelvic radiotherapy. J. Cell Mol. Med. 2019, 23, 3747-3756. [CrossRef] [PubMed]

48. Liu, X.; Shao, L.; Liu, X.; Ji, F.; Mei, Y.; Cheng, Y.; Liu, F.; Yan, C.; Li, L.; Ling, Z. Alterations of gastric mucosal microbiota across different stomach microhabitats in a cohort of 276 patients with gastric cancer. EBioMedicine 2019, 40, 336-348. [CrossRef] [PubMed]

49. Frasson, M.; Granero-Castro, P.; Ramos Rodriguez, J.L.; Flor-Lorente, B.; Braithwaite, M.; Marti Martinez, E.; Alvarez Perez, J.A.; Codina Cazador, A.; Espi, A.; Garcia-Granero, E.; et al. Risk factors for anastomotic leak and postoperative morbidity and mortality after elective right colectomy for cancer: Results from a prospective, multicentric study of 1102 patients. Int. J. Color. Dis. 2016, 31, 105-114. [CrossRef]

50. Tozun, N.; Vardareli, E. Gut Microbiome and Gastrointestinal Cancer: Les liaisons Dangereuses. J. Clin. Gastroenterol. 2016, 50 (Suppl. 2), S191-S196. [CrossRef]

51. Lin, L.T.; Shi, Y.C.; Choong, C.Y.; Tai, C.J. The Fruits of Paris polyphylla Inhibit Colorectal Cancer Cell Migration Induced by Fusobacterium nucleatum-Derived Extracellular Vesicles. Molecules 2021, 26, 4081. [CrossRef] [PubMed]

52. Yixia, Y.; Sripetchwandee, J.; Chattipakorn, N.; Chattipakorn, S.C. The alterations of microbiota and pathological conditions in the gut of patients with colorectal cancer undergoing chemotherapy. Anaerobe 2021, 68, 102361. [CrossRef] [PubMed]

53. Ralls, M.W.; Miyasaka, E.; Teitelbaum, D.H. Intestinal microbial diversity and perioperative complications. JPEN J. Parenter. Enter. Nutr. 2014, 38, 392-399. [CrossRef]

54. Shogan, B.D.; Belogortseva, N.; Luong, P.M.; Zaborin, A.; Lax, S.; Bethel, C.; Ward, M.; Muldoon, J.P.; Singer, M.; An, G.; et al. Collagen degradation and MMP9 activation by Enterococcus faecalis contribute to intestinal anastomotic leak. Sci. Transl. Med. 2015, 7, 286ra268. [CrossRef] [PubMed]

55. Hyoju, S.K.; Adriaansens, C.; Wienholts, K.; Sharma, A.; Keskey, R.; Arnold, W.; van Dalen, D.; Gottel, N.; Hyman, N.; Zaborin, A.; et al. Low-fat/high-fibre diet prehabilitation improves anastomotic healing via the microbiome: An experimental model. Br. J. Surg. 2020, 107, 743-755. [CrossRef]

56. Bloemen, J.G.; Schreinemacher, M.H.; de Bruine, A.P.; Buurman, W.A.; Bouvy, N.D.; Dejong, C.H. Butyrate enemas improve intestinal anastomotic strength in a rat model. Dis. Colon Rectum 2010, 53, 1069-1075. [CrossRef] [PubMed]

57. Mathew, A.J.; Wann, V.C.; Abraham, D.T.; Jacob, P.M.; Selvan, B.S.; Ramakrishna, B.S.; Nair, A.N. The effect of butyrate on the healing of colonic anastomoses in rats. J. Investig. Surg. 2010, 23, 101-104. [CrossRef] [PubMed]

58. Krezalek, M.A.; Hyoju, S.; Zaborin, A.; Okafor, E.; Chandrasekar, L.; Bindokas, V.; Guyton, K.; Montgomery, C.P.; Daum, R.S.; Zaborina, O.; et al. Can Methicillin-resistant Staphylococcus aureus Silently Travel From the Gut to the Wound and Cause Postoperative Infection? Modeling the "Trojan Horse Hypothesis". Ann. Surg. 2018, 267, 749-758. [CrossRef]

59. Siddharthan, R.; Chapek, M.; Warren, M.; Martindale, R. Probiotics in Prevention of Surgical Site Infections. Surg. Infect. (Larchmt) 2018, 19, 781-784. [CrossRef] [PubMed]

60. Moya, P.; Soriano-Irigaray, L.; Ramirez, J.M.; Garcea, A.; Blasco, O.; Blanco, F.J.; Brugiotti, C.; Miranda, E.; Arroyo, A. Perioperative Standard Oral Nutrition Supplements Versus Immunonutrition in Patients Undergoing Colorectal Resection in an Enhanced Recovery (ERAS) Protocol: A Multicenter Randomized Clinical Trial (SONVI Study). Medicine 2016, 95, e3704. [CrossRef]

61. Behera, H.S.; Chayani, N.; Bal, M.; Khuntia, H.K.; Pati, S.; Das, S.; Ranjit, M. Identification of population of bacteria from culture negative surgical site infection patients using molecular tool. BMC Surg. 2021, 21, 28. [CrossRef]

62. Ojima, M.; Motooka, D.; Shimizu, K.; Gotoh, K.; Shintani, A.; Yoshiya, K.; Nakamura, S.; Ogura, H.; Iida, T.; Shimazu, T. Metagenomic Analysis Reveals Dynamic Changes of Whole Gut Microbiota in the Acute Phase of Intensive Care Unit Patients. Dig. Dis. Sci. 2016, 61, 1628-1634. [CrossRef]

63. Wang, A.; Ling, Z.; Yang, Z.; Kiela, P.R.; Wang, T.; Wang, C.; Cao, L.; Geng, F.; Shen, M.; Ran, X.; et al. Gut microbial dysbiosis may predict diarrhea and fatigue in patients undergoing pelvic cancer radiotherapy: A pilot study. PLoS ONE 2015, 10, e0126312. [CrossRef]

64. Ley, R.E.; Backhed, F.; Turnbaugh, P.; Lozupone, C.A.; Knight, R.D.; Gordon, J.I. Obesity alters gut microbial ecology. Proc. Natl. Acad. Sci. USA 2005, 102, 11070-11075. [CrossRef] [PubMed]

65. Turnbaugh, P.J.; Ley, R.E.; Mahowald, M.A.; Magrini, V.; Mardis, E.R.; Gordon, J.I. An obesity-associated gut microbiome with increased capacity for energy harvest. Nature 2006, 444, 1027-1031. [CrossRef] [PubMed]

66. Motiani, K.K.; Collado, M.C.; Eskelinen, J.J.; Virtanen, K.A.; Loyttyniemi, E.; Salminen, S.; Nuutila, P.; Kalliokoski, K.K.; Hannukainen, J.C. Exercise Training Modulates Gut Microbiota Profile and Improves Endotoxemia. Med. Sci. Sports Exerc. 2020, 52, 94-104. [CrossRef] [PubMed] 
67. Lankelma, J.M.; van Vught, L.A.; Belzer, C.; Schultz, M.J.; van der Poll, T.; de Vos, W.M.; Wiersinga, W.J. Critically ill patients demonstrate large interpersonal variation in intestinal microbiota dysregulation: A pilot study. Intensive Care Med. 2017, 43, 59-68. [CrossRef] [PubMed]

68. Yang, Y.; Xia, Y.; Chen, H.; Hong, L.; Feng, J.; Yang, J.; Yang, Z.; Shi, C.; Wu, W.; Gao, R.; et al. The effect of perioperative probiotics treatment for colorectal cancer: Short-term outcomes of a randomized controlled trial. Oncotarget 2016, 7, 8432-8440. [CrossRef] [PubMed]

69. Sommacal, H.M.; Bersch, V.P.; Vitola, S.P.; Osvaldt, A.B. Perioperative synbiotics decrease postoperative complications in periampullary neoplasms: A randomized, double-blind clinical trial. Nutr. Cancer 2015, 67, 457-462. [CrossRef] [PubMed]

70. Darbandi, A.; Mirshekar, M.; Shariati, A.; Moghadam, M.T.; Lohrasbi, V.; Asadolahi, P.; Talebi, M. The effects of probiotics on reducing the colorectal cancer surgery complications: A periodic review during 2007-2017. Clin. Nutr. 2020, 39, $2358-2367$. [CrossRef]

71. Chung, Y.; Ryu, Y.; An, B.C.; Yoon, Y.S.; Choi, O.; Kim, T.Y.; Yoon, J.; Ahn, J.Y.; Park, H.J.; Kwon, S.K.; et al. A synthetic probiotic engineered for colorectal cancer therapy modulates gut microbiota. Microbiome 2021, 9, 122. [CrossRef]

72. Wei, D.; Heus, P.; van de Wetering, F.T.; van Tienhoven, G.; Verleye, L.; Scholten, R.J. Probiotics for the prevention or treatment of chemotherapy- or radiotherapy-related diarrhoea in people with cancer. Cochrane Database Syst. Rev. 2018, 8, CD008831. [CrossRef]

73. He, Y.; Wang, J.; Bian, H.; Deng, X.; Wang, Z. BMI as a Predictor for Perioperative Outcome of Laparoscopic Colorectal Surgery: A Pooled Analysis of Comparative Studies. Dis. Colon Rectum 2017, 60, 433-445. [CrossRef] [PubMed]

74. Weimann, A. Influence of nutritional status on postoperative outcome in patients with colorectal cancer-The emerging role of the microbiome. Innov Surg Sci 2018, 3, 55-64. [CrossRef]

75. Zhuang, C.L.; Huang, D.D.; Pang, W.Y.; Zhou, C.J.; Wang, S.L.; Lou, N.; Ma, L.L.; Yu, Z.; Shen, X. Sarcopenia is an Independent Predictor of Severe Postoperative Complications and Long-Term Survival After Radical Gastrectomy for Gastric Cancer: Analysis from a Large-Scale Cohort. Medicine 2016, 95, e3164. [CrossRef]

76. Sorg, J.A.; Sonenshein, A.L. Bile salts and glycine as cogerminants for Clostridium difficile spores. J. Bacteriol. 2008, 190, $2505-2512$. [CrossRef] [PubMed]

77. Chen, H.; Shen, L.; Liu, Y.; Ma, X.; Long, L.; Ma, X.; Ma, L.; Chen, Z.; Lin, X.; Si, L.; et al. Strength Exercise Confers Protection in Central Nervous System Autoimmunity by Altering the Gut Microbiota. Front. Immunol. 2021, 12, 628629. [CrossRef]

78. Palko-Labuz, A.; Maksymowicz, J.; Sobieszczanska, B.; Wikiera, A.; Skonieczna, M.; Wesolowska, O.; Sroda-Pomianek, K. Newly Obtained Apple Pectin as an Adjunct to Irinotecan Therapy of Colorectal Cancer Reducing E. coli Adherence and beta-Glucuronidase Activity. Cancers 2021, 13, 2952. [CrossRef]

79. Zheng, D.W.; Dong, X.; Pan, P.; Chen, K.W.; Fan, J.X.; Cheng, S.X.; Zhang, X.Z. Phage-guided modulation of the gut microbiota of mouse models of colorectal cancer augments their responses to chemotherapy. Nat. Biomed. Eng. 2019, 3, 717-728. [CrossRef]

80. Le Bastard, Q.; Al-Ghalith, G.A.; Gregoire, M.; Chapelet, G.; Javaudin, F.; Dailly, E.; Batard, E.; Knights, D.; Montassier, E. Systematic review: Human gut dysbiosis induced by non-antibiotic prescription medications. Aliment. Pharmacol. Ther. 2018, 47, 332-345. [CrossRef] [PubMed]

81. Pettigrew, M.M.; Gent, J.F.; Kong, Y.; Halpin, A.L.; Pineles, L.; Harris, A.D.; Johnson, J.K. Gastrointestinal Microbiota Disruption and Risk of Colonization With Carbapenem-resistant Pseudomonas aeruginosa in Intensive Care Unit Patients. Clin. Infect. Dis. 2019, 69, 604-613. [CrossRef]

82. Rollins, K.E.; Javanmard-Emamghissi, H.; Acheson, A.G.; Lobo, D.N. The Role of Oral Antibiotic Preparation in Elective Colorectal Surgery: A Meta-analysis. Ann. Surg. 2019, 270, 43-58. [CrossRef]

83. Wong, S.H.; Zhao, L.; Zhang, X.; Nakatsu, G.; Han, J.; Xu, W.; Xiao, X.; Kwong, T.N.Y.; Tsoi, H.; Wu, W.K.K.; et al. Gavage of Fecal Samples From Patients With Colorectal Cancer Promotes Intestinal Carcinogenesis in Germ-Free and Conventional Mice. Gastroenterology 2017, 153, 1621-1633.e1626. [CrossRef]

84. Chang, C.W.; Lee, H.C.; Li, L.H.; Chiang Chiau, J.S.; Wang, T.E.; Chuang, W.H.; Chen, M.J.; Wang, H.Y.; Shih, S.C.; Liu, C.Y.; et al. Fecal Microbiota Transplantation Prevents Intestinal Injury, Upregulation of Toll-Like Receptors, and 5-Fluorouracil/OxaliplatinInduced Toxicity in Colorectal Cancer. Int. J. Mol. Sci. 2020, 21, 386. [CrossRef]

85. DeFilipp, Z.; Bloom, P.P.; Torres Soto, M.; Mansour, M.K.; Sater, M.R.A.; Huntley, M.H.; Turbett, S.; Chung, R.T.; Chen, Y.B.; Hohmann, E.L. Drug-Resistant E. coli Bacteremia Transmitted by Fecal Microbiota Transplant. N. Engl. J. Med. 2019, 381, 2043-2050. [CrossRef]

86. Trubiano, J.A.; Gardiner, B.; Kwong, J.C.; Ward, P.; Testro, A.G.; Charles, P.G. Faecal microbiota transplantation for severe Clostridium difficile infection in the intensive care unit. Eur. J. Gastroenterol. Hepatol. 2013, 25, 255-257. [CrossRef] [PubMed]

87. Quera, R.; Espinoza, R.; Estay, C.; Rivera, D. Bacteremia as an adverse event of fecal microbiota transplantation in a patient with Crohn's disease and recurrent Clostridium difficile infection. J. Crohns Colitis 2014, 8, 252-253. [CrossRef]

88. Baxter, M.; Ahmad, T.; Colville, A.; Sheridan, R. Fatal Aspiration Pneumonia as a Complication of Fecal Microbiota Transplant. Clin. Infect. Dis. 2015, 61, 136-137. [CrossRef] [PubMed]

89. Wang, C.; Li, Q.; Ren, J. Microbiota-Immune Interaction in the Pathogenesis of Gut-Derived Infection. Front. Immunol. 2019, 10, 1873. [CrossRef] [PubMed]

90. Fay, K.T.; Klingensmith, N.J.; Chen, C.W.; Zhang, W.; Sun, Y.; Morrow, K.N.; Liang, Z.; Burd, E.M.; Ford, M.L.; Coopersmith, C.M. The gut microbiome alters immunophenotype and survival from sepsis. FASEB J. 2019, 33, 11258-11269. [CrossRef] 
91. Gerassy-Vainberg, S.; Blatt, A.; Danin-Poleg, Y.; Gershovich, K.; Sabo, E.; Nevelsky, A.; Daniel, S.; Dahan, A.; Ziv, O.; Dheer, R.; et al. Radiation induces proinflammatory dysbiosis: Transmission of inflammatory susceptibility by host cytokine induction. Gut 2018, 67, 97-107. [CrossRef] [PubMed]

92. Nakatsu, G.; Zhou, H.; Wu, W.K.K.; Wong, S.H.; Coker, O.O.; Dai, Z.; Li, X.; Szeto, C.H.; Sugimura, N.; Lam, T.Y.; et al. Alterations in Enteric Virome Are Associated With Colorectal Cancer and Survival Outcomes. Gastroenterology 2018, 155, 529-541.e525. [CrossRef] [PubMed]

93. Shao, D.; Vogtmann, E.; Liu, A.; Qin, J.; Chen, W.; Abnet, C.C.; Wei, W. Microbial characterization of esophageal squamous cell carcinoma and gastric cardia adenocarcinoma from a high-risk region of China. Cancer 2019, 125, 3993-4002. [CrossRef] [PubMed]

94. Garajova, I.; Balsano, R.; Wang, H.; Leonardi, F.; Giovannetti, E.; Deng, D.; Peters, G.J. The role of the microbiome in drug resistance in gastrointestinal cancers. Expert Rev. Anticancer Ther. 2021, 21, 165-176. [CrossRef] [PubMed]

95. Li, D.; He, R.; Hou, G.; Ming, W.; Fan, T.; Chen, L.; Zhang, L.; Jiang, W.; Wang, W.; Lu, Z.; et al. Characterization of the Esophageal Microbiota and Prediction of the Metabolic Pathways Involved in Esophageal Cancer. Front. Cell Infect. Microbiol. 2020, 10, 268. [CrossRef] 